І.В. Корнієнко ${ }^{1}$, С.П. Корнієнко ${ }^{1}$, В.А. Дмитрієв ${ }^{2}$, А.Г. Павленко ${ }^{2}$, Д.О. Камак ${ }^{2}$

${ }^{1}$ Наџіональний університет “Чернігівська політехніка”, Чернігів

${ }^{2}$ Державний науково-дослідний інститут випробувань і сертифікації озброєння та військової техніки, Чернігів

\title{
АЛГОРИТМ СКОРОЧЕННЯ КІЛЬКОСТІ ДОСЛІДІВ ПРИ ВИКОРИСТАННІ ІНТЕРВАЛЬНИХ ОЦІНОК ЯКОСТІ ВИПРОБУВАНОГО ЗРАЗКА ОЗБРОЄННЯ ТА ВІЙСЬКОВОЇ ТЕХНІКИ
}

У статті розглянуті теоретичні питання формування необхідних і достатніх умов для забезпечення якості інтервальних оцінок досліджуваних стохастичних параметрів і характеристик випробуваних зразків озброєння та військової техніки. Особливістю використання інтервальної оцінки результатів випробування зразків є підтвердження належної якості їх стохастичних параметрів та характеристик в інтервалі від гарантованої розробником імовірності реалізаиії параметру чи характеристики до максимальної (мінімальної) можливої. За рахунок використання інтервальних оцінок можливе застосування гнучких планів випробування зразків озброєння та військової техніки, які дозволяють певним чином скорочувати обсяг серій натурних дослідів, які забезпечують належну якість одержуваної оцінки. Для практичної реалізації гнучкого плану до задачі масових випробувань зразків озброєння та військової техніки розроблений алгоритм, який підлягає програмній реалізаиії на мобільному пристрої.

Ключові слова: автоматизація, випробування, оцінка, точність, надійність, озброєння та військова техніка.

\section{Вступ}

Постановка проблеми. Випробування озброєння та військової техніки (ОВТ) є відповідальною задачею державного рівня, причому результати випробувань, що проводяться на різних етапах життєвого циклу мають відповідати заданому рівню достовірності. Достовірність випробувань прийнято визначати через точність і надійність одержуваних в результаті випробувань оцінок параметрів і характеристик зразків. Складності забезпечення якості оцінок результатів випробування виявляються при досліджені стохастичних параметрів випробувальних зразків, коли точність і надійність оцінки забезпечуються результатами статистичного експерименту, а саме частотою настання "сприятливої” події підтвердження показника досліджуваного параметру чи характеристики зразку.

Проблема виникає на етапі набуття достатньої кількості “сприятливих" подій, де якість оцінки може забезпечуватись кількома сотнями "успіхів". Це не викликає проблеми при випробуванні наприклад стрілецької зброї, де вартість одного пострілу є доволі низькою. 3 іншого боку, масові повторення дослідів практично неможливі при випробуванні наприклад крилатих ракет, де дослідні зразки випускаються у штучному варіанті, їх вартість доволі висока, тривалість випробувань займає значний часовий інтервал, та й масові полігонні випробування такої зброї несуть серйозні загрози екології довкілля.

Звідси виникає проблема забезпечення якості оцінки параметрів та характеристик випробуваного зразку за мінімальної кількості повторень дослідів.

Аналіз останніх досліджень та публікацій. Питання, пов'язані з випробуваннями ОВТ викладені у низці нормативних актів, відомчих наказів та методичних рекомендацій, наприклад [1-4]. Незважаючи на це, на сьогодні відсутні єдиний універсальний методичний підхід до організації та проведення випробувань ОВТ, у тому числі у питанні планування кількісних показників випробувань. Відповідно, дослідники мають користуватися існуючими розвинутими математичними апаратами планування та математичної обробки результатів експериментів, наприклад [5-9], а також положеннями теорії і практики дослідження стохастичних величин та їх статистичного оцінювання, наприклад [10-16].

На сучасному етапі продовжується розвиток теорії і практики експериментальних досліджень та пошуку компромісів між витратами при проведенні експерименту та якістю одержуваної оцінки випробуваної стохастичної величини [17-22].

У нашому випадку, коли здійснюються масові випробування зразків ОВТ (у тому числі на різних стадіях їх життєвого циклу), критичним для функціонування випробувальної установи $є$ ресурси, що витрачаються на проведення випробувань. Для пошуку оптимальних режимів функціонування випро- 
бувальної установи та необхідних ресурсів у [23] досліджувану систему випробувань представлено багатоканальною моделлю СМО. При досліджені діяльності випробувального інституту авторами встановлено, що чимало людських та часових ресурсів витрачається на підготовчому етапі випробувань, для зменшення яких у [24] запропоновано використання підсистеми автоматизованого планування та управління якістю випробувань. У [25] запропоновано використання модулю розрахунку кількісних параметрів випробувань, а у [26-27] розглянуто математичний апарат для застосування у програмному модулі з метою формування кількісних планів одержання точкових та інтервальних оцінок результатів випробувань заданої якості.

Однією з основних проблем при одержанні якісних оцінок стохастичного параметру або характеристики натурно випробуваного зразка є достатньо велика кількість повторень випробувань, причому, для підтвердження оцінки може знадобитись навіть декілька серій випробувань, що показане у [21; 26]. Проте, у чисельних випадках при випробуванні зразків військового призначення, утрудненим $\epsilon$ навіть дрібносерійні дослідження через руйнівну природу окремих дослідів, велику вартість або фізичну неможливість таких випробувань (наприклад стійкість при попаданні снарядів, протимінний захист бронетехніки, реакція засобів зв'язку та автоматизації на електромагнітний імпульс тощо). Тому представляє інтерес розгляд можливих способів зменшення кількості випробувань. В [27] показано, що при одержанні інтервальних оцінок, тобто у випадку підтвердження параметру або характеристики виробу у вигляді "не більше ніж" або "не менше ніж", можна суттєво скоротити загальну кількість повторень випробування. Сутність скорочення ітерацій випробування полягає у припиненні повторень дослідів у випробуваннях параметру чи характеристики зразка ОВТ за умови підтвердження якості одержаної інтервальної оцінки (тобто оцінки обмеженої “зверху" або “знизу”). Для цього потрібно мати чіткі умови необхідності і достатності якості інтервальної оцінки.

Мета статті. Розробити, підготувати та алгоритмізувати механізм скорочення серії дослідів стохастичного параметру або характеристики випробуваного зразку при досягненні одержуваної оцінки заданої якості.

\section{Виклад основного матеріалу}

Зменшення витрат ресурсів на проведення випробувань в багатьом залежить від ступеня автоматизації робіт та процесів на всіх етапах випробування, у тому числі на етапі підготовки до випробувань та оцінки одержаних результатів. У [26] запропоновано фрагмент підсистеми планування та управління випробуваннями (рис. 1) в частині розрахунку кількісного плану випробувань відповідно до висунутих вимог (більш загальне представлення даного функціонального модулю наведене у [25]).

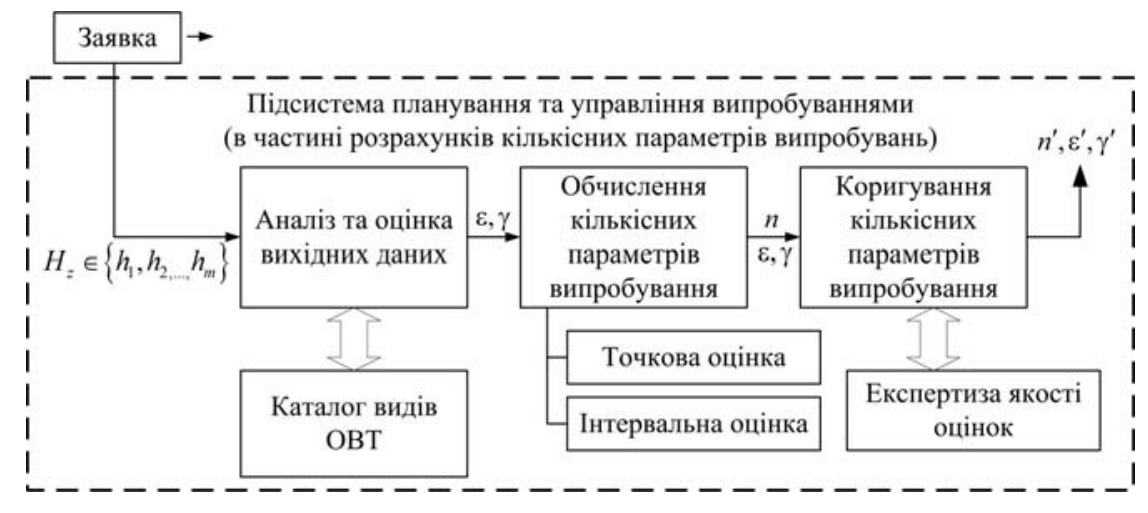

Рис. 1. Фрагмент підсистеми планування та управління випробуваннями Джерело: розроблено авторами.

На схемі рис. 1 позначено $H_{z} \in\left\{h_{1}, h_{2, \ldots,} h_{m}\right\}-$ заданий набір параметрів випробувального зразка, $n$ - кількість випробувань, $\varepsilon, \gamma$ - відповідно точність та надійність оцінок випробування, $n^{\prime}, \varepsilon^{\prime}, \gamma^{\prime}-$ кориговані показники кількості випробувань, точності та надійності оцінок.

Зауважимо, що існує два можливих випадки планування кількості випробувань, які визначаються конкретним видом випробування, а саме:
1) первинне визначення стохастичного параметра або характеристики зразка, або підтвердження параметру (характеристики), для якого початкова ймовірність реалізації невідома або недостовірна.

2) підтвердження параметру (характеристики) досліджуваного зразка при заданій початковій імовірності для його реалізації, тобто в результаті випробувань необхідно підтвердити початкову ймовірність.

В рамках мети статті зазначимо, що розгляду 
підлягає випадок, коли розробником зразка ОВТ задана початкова ймовірність реалізації певного стохастичного параметра або характеристики, при цьому необхідно одержати інтервальну оцінку досліджуваного параметру (характеристики), тобто таку оцінку, що характеризує одержуване підтвердження оцінюваного параметру як “не гірше ніж” задана початкова характеристика його реалізації.

У [27] визначалося, що інтервальна оцінка стохастичного параметра чи характеристики досліджуваного зразка є дещо “послабленим” випадком точкової характеристики. Термін “послаблення” визначає можливе зменшення загальної кількості повторень при випробуваннях зразка ОВТ без втрати якості одержуваної стохастичної оцінки.

Незважаючи, що у [27] приведені основні викладки щодо можливого скорочення кількості повторень дослідів, розглянемо більш докладно умови, що забезпечують таку можливість. Мінімальнонеобхідна кількість повторень випробувань $n$ у випадку заданої початкової ймовірнісної характеристики, відповідно до $[10 ; 13 ; 26]$ становить

$$
n \geq\left(\frac{x_{\gamma}}{\varepsilon}\right)^{2} p q
$$

де $x_{\gamma}$ - аргумент функції Лапласа;

$\varepsilon$ - точність одержуваної оцінки;

$p$ - початкова ймовірність реалізації параметра (характеристики) досліджуваного зразку;

$q$ - ймовірність ненастання “успіху” у результаті випробування, $q=1-p$.

В даному випадку початкова ймовірність реалізації параметра (характеристики) представляє собою точкову оцінку, тобто в процесі випробувань ми досліджуємо наскільки той чи інший параметр (характеристика) зразка наближена у своїй реалізації до значення $p$. Сутність оцінювання параметру “не гірше ніж” полягає у підтвердженні ймовірності настання успішної реалізації досліджуваного параметру $p^{\prime}$, яка перебуває в межах $p \leq p^{\prime}<1$ (для випадку “не більше ніж” межі становитимуть $\left.0<p^{\prime} \leq p\right)$. Тобто в процесі досліджень встановлена оцінка ймовірності настання успіху $p^{\prime}$ “краща”, ніж задана початкова ймовірність $p$. В цьому випадку, кількість дослідів може бути дещо скорочена, що зазначалося у [26-27], але не може бути меншою за кількість $n^{\prime}$, які забезпечують оцінку ймовірності $p^{\prime}$ при заданих параметрах якості $\gamma$ i $\varepsilon$, а отже має виконуватись нерівність

$$
n^{\prime} \geq\left(\frac{x_{\gamma}}{\varepsilon}\right)^{2} p^{\prime} q^{\prime} ; q^{\prime}=1-p^{\prime} .
$$

За умови, що $p \geq 0,5$ ( $p=0,5$ це найгірший випа- док повної невизначеності щодо успішності реалізації параметру (характеристики) випробуваного зразка [26]), при дослідженні параметру “не гірше ніж” (а фактично прийнятої нами умови $p \leq p^{\prime}$ ), завжди виконується нерівність $p q \geq p^{\prime} q^{\prime}$. 3 урахуванням того, що ми шукаємо мінімально-необхідну кількість повторень дослідів, то знак " $\geq$ “ у виразі (2) визначає мінімальне значення $n^{\prime}$, яке задовольняє нерівності (2) та округлене до найбільшого цілого числа. Тоді значення $n^{\prime}$, яке визначає можливе скорочення кількості повторень дослідів, має знаходитись у інтервалі: $\left(\frac{x_{\gamma}}{\varepsilon}\right)^{2} p q>n^{\prime} \geq\left(\frac{x_{\gamma}}{\varepsilon}\right)^{2} p^{\prime} q^{\prime}$, а 3 урахуванням (1):

$$
n>n^{\prime} \geq\left(\frac{x_{\gamma}}{\varepsilon}\right)^{2} p^{\prime} q^{\prime} .
$$

Показники якості одержуваної оцінки встановлюють певний довірчий інтервал. При потраплянні статистичної частоти успішної реалізації параметру (характеристики) у довірчий інтервал, утворюваний заданою первиною ймовірністю та параметрами надійності і точності оцінки, випробування вважаються успішними. Тут, 3 точки зору можливості скорочень кількості повторень дослідів, оцінці підлягає ширина довірчого інтервалу, так як важливим $\epsilon$ те, щоб при умові $p^{\prime} \geq p$ нижня межа початкової імовірності $p$ “перекривала" нижню межу оцінки $p^{\prime}$, тобто необхідно, щоб довірчий інтервал оцінки $p^{\prime}$ не був “ширшим” довірчого інтервалу $p$. Відомо, що для заданих надійності $\gamma$ і точності $\varepsilon$ межі довірчого інтервалу визначаються умовою [26]:

$$
P(|W-p|<\varepsilon) \approx \gamma,
$$

де $W$ - статистична частота “успіху” при випробуваннях; тобто прийнятними для $\gamma$ вважаються межі довірчого інтервалу $(W-\varepsilon \leq p \leq W+\varepsilon)$.

Звідси видно, що ширина довірчого інтервалу визначається величиною точності $\varepsilon$, причому $\varepsilon=x_{\gamma} \sqrt{\frac{p q}{n}}$. Відповідно, ширина довірчого інтервалу (4) для оцінки ймовірності $p^{\prime}: p^{\prime} \geq p$ потенційно не може бути “ширшим” за довірчій інтервал початкової ймовірності $p$, так як $p^{\prime} q^{\prime} \leq p q$ (для прикладу та порівняння ширини довірчого інтервалу для надійності оцінки $\gamma=0,95$, початкової ймовірності $p=0,8$ та оцінки ймовірнісної характеристики $p^{\prime}=0,9$ зображено на рис. 2).

Вважаючи, що скорочення випробувань відбувається безпосередньо у процесі випробувань, тобто рішення про достатність випробувань приймається 
при проведеній кількості дослідів $n^{\prime}$ та відомому числі успішних реалізацій $k$, постає зворотна задача розрахунку ймовірності, яку забезпечує така реалізація $k$ при даній кількості повторень $n^{\prime}$ з заданими параметрами якості $\gamma$ i $\varepsilon$.

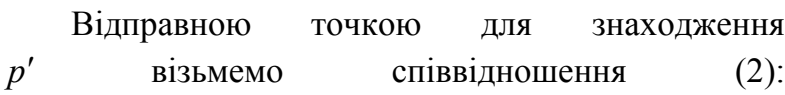

$-\left(\frac{x_{\gamma}}{\varepsilon}\right)^{2}\left(p^{\prime}\right)^{2}+\left(\frac{x_{\gamma}}{\varepsilon}\right)^{2} p^{\prime}-n^{\prime} \leq 0$. Коренями відповідного квадратного рівняння є значення оцінки ймовірності $p^{\prime}$ для випадків “не гірше ніж” - $p^{\prime *}$ та “не більше ніж"- $p_{*}^{\prime}$ :

$$
\begin{gathered}
p^{\prime *}=\frac{\left(\frac{x_{\gamma}}{\varepsilon}\right)^{2}+\sqrt{\left(\frac{x_{\gamma}}{\varepsilon}\right)^{4}-4\left(\frac{x_{\gamma}}{\varepsilon}\right)^{2} n^{\prime}}}{2\left(\frac{x_{\gamma}}{\varepsilon}\right)^{2}} ; \\
p^{\prime *}=\frac{\left(\frac{x_{\gamma}}{\varepsilon}\right)^{2}-\sqrt{\left(\frac{x_{\gamma}}{\varepsilon}\right)^{4}-4\left(\frac{x_{\gamma}}{\varepsilon}\right)^{2} n^{\prime}}}{2\left(\frac{x_{\gamma}}{\varepsilon}\right)^{2}} .
\end{gathered}
$$

Графічна інтерпретація знайдених рішень забезпечення оцінки імовірності $p^{\prime}$ для надійності оцінки $\gamma=0,95$, точності $\varepsilon=0,1$ наведена на рис. 3 .

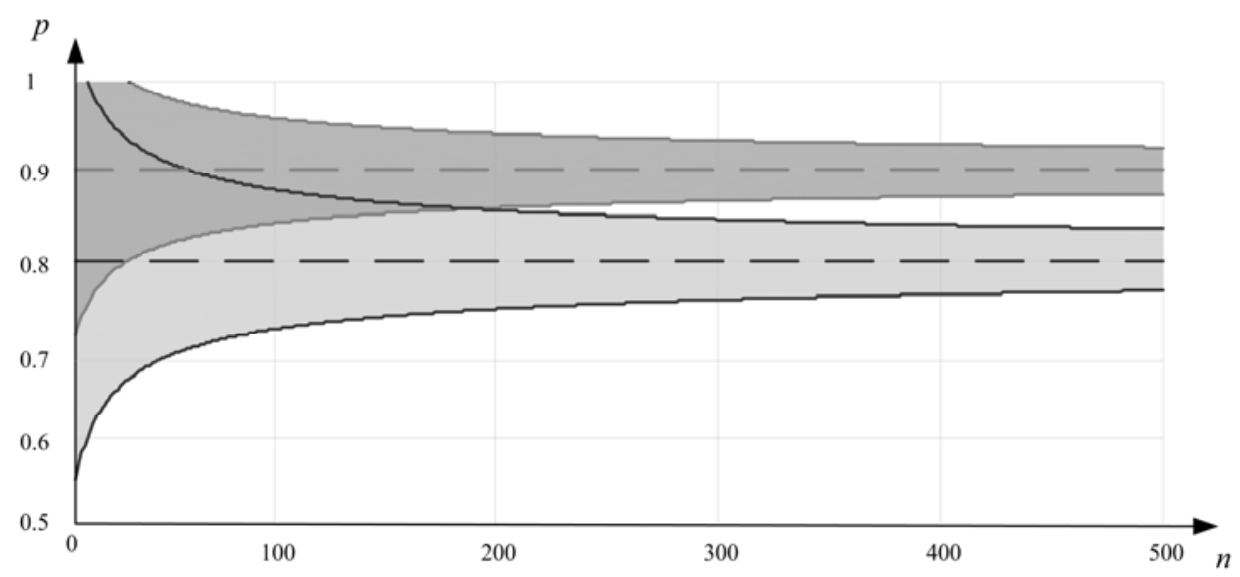

Рис. 2. Ширина довірчих інтервалів, для випадків $p=0,8$ та $p^{\prime}=0,9$

Джерело: розроблено авторами.

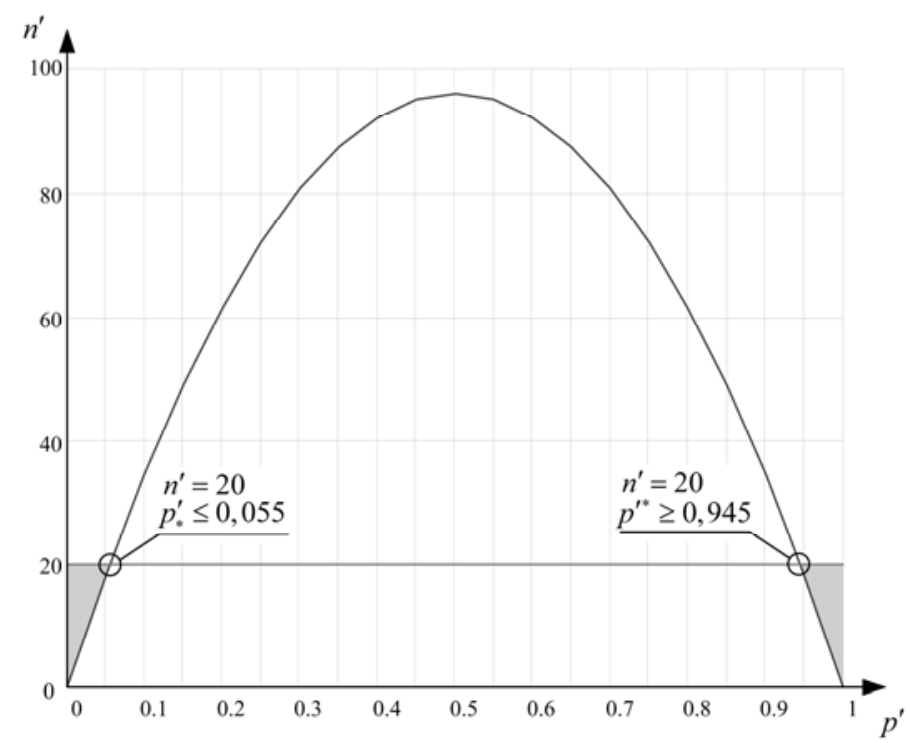

Рис. 3. Графічна інтерпретація розрахунку імовірності $p^{\prime}$, яку забезпечує кількість проведених повторень $n^{\prime}=20$ з заданими параметрами якості $\gamma$ і $\varepsilon$

Джерело: розроблено авторами. 
Таким чином, одержані з (5-6) значення оцінок ймовірності $p$ ' для інтервальних оцінок “не гірше ніж” та “не більше ніж”, після підставлення в (3), завершують необхідні та достатні умови для забезпечення якості оцінок випробування та створюють основу для іiі зручного застосування у обчислювальному алгоритмі. Блок схема алгоритму скорочення кількості випробувань при інтервальних оцінках стохастичних параметрів (характеристик) випробуваного зразку ОВТ наведена на рис. 4.

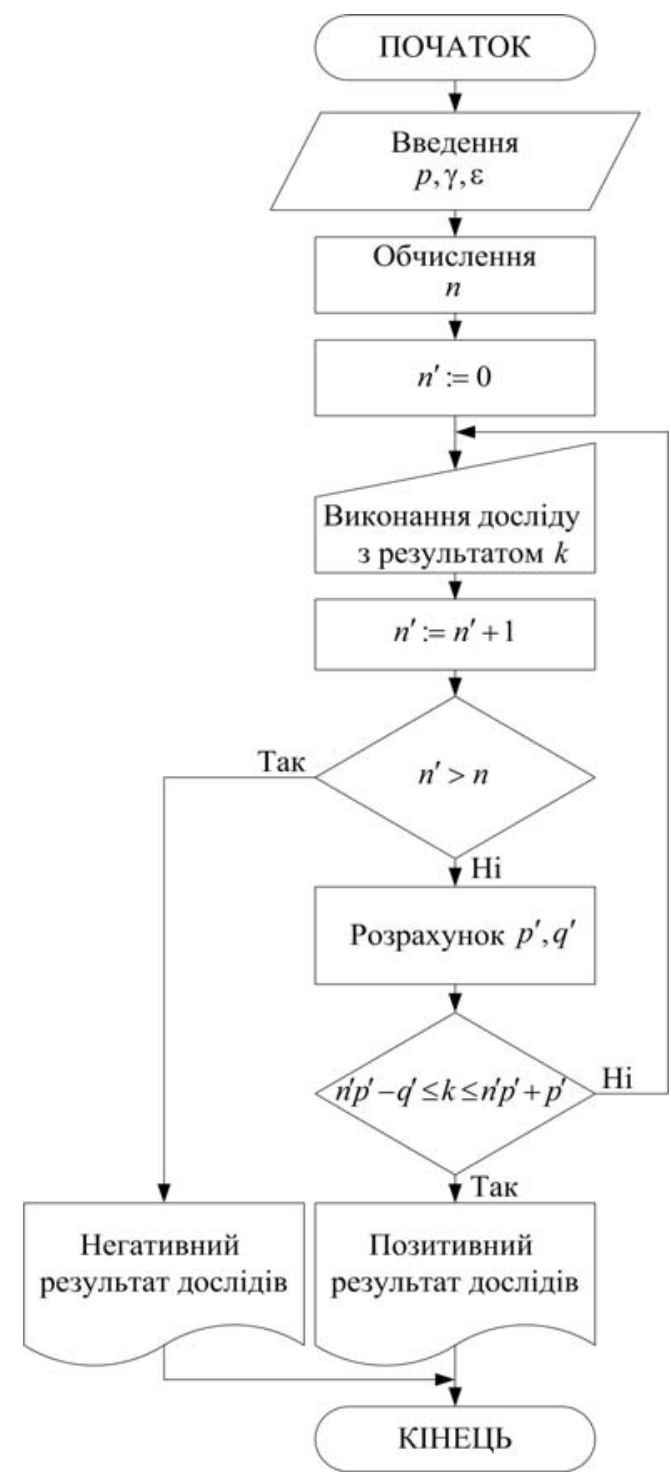

Рис. 4. Алгоритм можливого скорочення кількості випробування з одержанням інтервальної оцінки, яка відповідає заданим $p, \gamma, \varepsilon$ Джерело: розроблено авторами.
Мінімально необхідна кількість випробувань $n$ обчислюється за виразом (1). Розрахунок $p^{\prime}, q^{\prime}$ здійснюється за допомогою формул $(5-6 ; 2)$ Переривання алгоритму 3 одержанням негативного результату дослідів здійснюється у випадку невиконання умови (3), тобто фактичному перевищенню проведеної кількості випробувань $n^{\prime}$ розрахованої кількості випробувань $n$ і неодержанням підтвердження реалізації початкової ймовірнісної характеристики $p$.

Позитивний результат дослідів одержується у результаті виконання нерівності для числа “успішних" дослідів $k$ [26]: $n^{\prime} p^{\prime}-q^{\prime} \leq k \leq n^{\prime} p^{\prime}+p^{\prime}$, яке одержане при проведенні $n^{\prime}$ дослідів, які в свою чергу забезпечують імовірність $p^{\prime}, q^{\prime}=1-p^{\prime} \quad 3$ заданими параметрами якості оцінки $\gamma$ i $\varepsilon$.

3 алгоритму видно, що у процесі досліджень необхідна ітераційна операція введення "успішного" результату досліду $k$, що потребує “ручного” введення після кожного випробування.

Відповідно до цього, алгоритм має бути реалізований у програмному забезпеченні на мобільному пристрої, використання якого в польових умовах, при виконанні умови $p^{\prime}>p\left(p^{\prime}<p\right)$ та заданих $\gamma$ i $\varepsilon$, дозволить дочасно припинити випробування.

\section{Висновки}

Запропоновано механізм одержання інтервальної оцінки в ході випробування стохастичних параметрів та характеристик зразка, яка відповідає висунутим вимогам до ії надійності і точності, і в той же час створює можливість скорочення серії випробувань.

Застосування запропонованого механізму можливо у випадку, коли не потрібно підтверджувати задану розробником імовірнісну характеристику, тобто одержувати точкову оцінку якості зразку, але потрібно переконатися, що якість стохастичного параметра або характеристики зразка не гірша, ніж заявлена розробником.

Для практичної реалізації механізму розроблено алгоритм, який нескладно реалізувати у програмному застосуванні на мобільному пристрої, що дозволить у польових умовах припинити серію випробувань при підтвердженні якості параметрів та характеристик випробуваного зразку ОВТ.

\section{Список літератури}

1. ДСТУ 3021-95. Випробування і контроль якості продукції. Терміни та визначення. - К., 1995. - 71 с.

2. ГОСТ В 15.210-78. СРПП ВТ. Система разработки и постановки на производство военной техники. Испытания опытных образцов изделий. - М., 2001. -47 с.

3. ГОСТ В 15.211-78. СРПП ВТ. Порядок разработки программ и методик испытаний опытных образцов изделий. Основные положения. - М., 1979. - 23 с.

4. ГОСТ В 15.307-77. СРПП ВТ. Испытания и приемка серийных изделий. Основные положения. - М., 1979. - 37 с.

5. Хартман К. Планирование эксперимента в исследовании технологических процессов / К. Хартман, Э. Лецкий, 
В. Шеффер. - М.: Мир, 1977. - 541 с.

6. Адлер Ю.П. Планирование эксперимента при поиске оптимальных условий / Ю.П. Адлер, Е.В. Маркова, Ю.В. Грановский. - М.: Наука, 1976. - 279 с.

7. Тихомиров В.Б. Планирование и анализ эксперимента (при проведении исследований в легкой и текстильной промышленности) / В.Б. Тихомиров. - М.: Легкая индустрия, 1974. - 262 с.

8. Джонсон Н. Статистика и планирование эксперимента в технике и науке: Методы планирования эксперимента / Н. Джонсон, Ф. Лион. - М.: Мир, 1981. - 520 с.

9. Дмитриев А.К. Элементы теории испытаний и контроля технических систем / А.К. Дмитриев, В.М. Марков,

В.И. Городецкий. - Ј.: Энергия, 1978. - 192 с.

10. Гнєденко Б.В. Курс теорії ймовірностей / Б.В. Гнєденко. - К.: - Рад. шк., 1949. - 360 с.

11. Вентцель Е.С. Теория вероятностей / Е.С. Вентцель. - М.: Наука, 1969. - 576 с.

12. Крамер Г. Математические методы статистики / Г. Крамер. - М.: Мир, 1975. -648 с.

13. Гмурман В.Е. Теория вероятностей и математическая статистика. - М.: Высшая школа, 1977. -479 с.

14. Колмогоров А.Н. Основные понятия теории вероятностей / А.Н. Колмогоров. - М.: Наука, 1974. - 120 с.

15. Вентцель Е.С. Теория вероятностей и ее инженерные приложения / Е.С. Вентцель, Л.А. Овчаров. - М.: Наука, 1988. $-480 \mathrm{c}$.

16. Шефтель 3.Г. Теорія ймовірностей: підручник. - 2-ге вид., переробл. і допов. / З.Г. Шефтель. - К.: Вища шк., 1994. $-192 \mathrm{c}$.

17. Лантух-Лященко А.І. Стохастична експертна оцінка технічного стану споруди в автоматизованій системі управління мостами / А.І. Лантух-Лященко // Мости та тунелі: теорія, дослідження, практика. -2019. - № 15. - С. 34-40. https://doi.org/10.15802/bttrp2019/172377.

18. Чекурін В. Статистична модель довговічності скла за статичного навантаження. Логарифмічно нормальний розподіл ймовірності / В. Чекурін, В. Лазар, В. Дяків // Фізико-математичне моделювання та інформаційні технології. 2008. - № 8. - С. 186-197.

19. Щапов П.Ф. Методи підвищення вірогідності контролю та діагностики стохастичних параметрів об'єктів різної фізичної природи: дис. ... д-ра. техн. наук: спец 05.11.13 - “Прилади і методи контролю та визначення складу речовин”. - X., 2009. - $39 \mathrm{c}$.

20. Кошевая Л.А. Обеспечение единства испытаний. Концептуальные основы: монография / Л.А. Кошевая. - К.: HAУ, 2009. - $176 \mathrm{c}$.

21. Планування експерименту при розв'язанні оберненої задачі побудови толерантних (референсних) інтервалів / С.В. Гадецька, В.Ю. Дубницький, Ю.І. Кушнерук, О.І. Ходирєв // Системи обробки інформації. - 2020. - № 2(161). C. 37-46. https://doi.org/10.30748/soi.2020.161.05.

22. Дмитрієв В.А. Методичний підхід до обгрунтування можливості зменшення експериментів в процесі проведення випробувань / В.А. Дмитрієв, А.І. Сергієнко, Ю.М. Тішков // Збірник наукових праць “Труди академії”. - 2008. № 7(87). - С. 63-67.

23. Графічне представлення моделі функціонування випробувальної організації / І.В. Корнієнко, С.П. Корнієнко, О.М. Походенко, С.М. Казначей, О.В. Руденко // Збірник наукових праць Державного науково-дослідного інституту випробувань і сертифікації озброєння та військової техніки. - 2019 . - № $2 . \quad$ - С. 91-98. https://doi.org/10.37701/dndivsovt.2.2019.13.

24. Автоматизація підсистеми планування випробувань / І.В. Корнієнко, Д.О. Камак, О.В. Руденко, С.В. Москалець // Збірник матеріалів тез доповідей Х Міжнародної науково-практичної конференції "Комплексне забезпечення якості технологічних процесів та систем (КЗЯТПС - 2020)”. - Чернігів, 29-30 квітня 2020 р. - Т. 2. - С. 206.

25. Забезпечення якості оцінок випробувань / С.П. Корнієнко, В.А. Дмитрієв, А.Г. Павленко, С.М. Казначей // Збірник матеріалів тез доповідей X Міжнародної науково-практичної конференції “Комплексне забезпечення якості технологічних процесів та систем (КЗЯТПС - 2020)”. - Чернігів, 29-30 квітня 2020 р. - Т. 2. - С. 207.

26. Формування кількісних характеристик випробувань для одержання точкових оцінок заданої якості / С. Корнієнко, І. Корнієнко, В. Дмитрієв, А. Павленко, Д. Камак // Технічні науки та технології. - 2020. - № 1(19). - С. 140-155. https://doi.org/10.25140/2411-5363-2020-1(19)-140-155.

27. Планування кількості випробувань при інтервальних оцінках зразків ОВТ / С.П. Корнієнко, І.В. Корнієнко, Д.О. Камак, С.М. Казначей, О.В. Жирна // Збірник наукових праць Державного науково-дослідного інституту випробувань і сертифікації озброєння та військової техніки. - 2020. - № 4. - С. 46-54. https://doi.org/10.37701/dndivsovt.4.2020.06.

Надійшла до редколегії 30.09.2020

Схвалена до друку 17.11.2020

\section{Відомості про авторів:}

\section{Корнієнко Ігор Валентинович}

кандидат технічних наук доцент завідувач кафедри Національного університету

"Чернігівська політехніка",

Чернігів, Україна

https://orcid.org/0000-0001-9105-0780

\section{Корніснко Світлана Петрівна}

кандидат технічних наук доцент доцент

Національного університету

"Чернігівська політехніка",

Чернігів, Україна

https://orcid.org/0000-0002-9162-1229
Information about the authors:

Ihor Korniienko

Candidate of Technical Sciences Associate Professor

Head of Department

of Chernihiv Polytechnik National University,

Chernihiv, Ukraine

https://orcid.org/0000-0001-9105-0780

Svitlana Korniienko

Candidate of Technical Sciences Associate Professor

Senior Lecturer

of Chernihiv Polytechnik National University,

Chernihiv, Ukraine

https://orcid.org/0000-0002-9162-1229 
Дмитрієв Володимир Анатолійович

кандидат технічних наук старший науковий співробітник заступник начальника інституту 3 наукової роботи

Державного науково-дослідного інституту

випробувань і сертифікації

озброєння та військової техніки,

Чернігів, Україна

https://orcid.org/0000-0002-0792-6397

\section{Павленко Анатолій Григорович}

кандидат технічних наук начальник

науково-організаційного відділу

Державного науково-дослідного інституту випробувань сертифікації озброєння та військової техніки,

Чернігів, Україна

https://orcid.org/0000-0001-6341-8381

\section{Камак Дмитро Олександрович}

начальник науково-дослідного відділу

Державного науково-дослідного інституту випробувань і

сертифікації озброєння та військової техніки,

Чернігів, Україна

https://orcid.org/0000-0003-0348-5456
Volodymyr Dmytriiev

Candidate of Technical Sciences Senior Research

Deputy Chief of Institute of Research Work

of State Scientific Research Institute

of Armament and Military Equipment

Testing and Certification,

Chernihiv, Ukraine

https://orcid.org/0000-0002-0792-6397

\section{Anatolii Pavlenko}

Candidate of Technical Sciences Chief of the Scientific Organizational Department of State Scientific Research Institute of Armament and Military Equipment

Testing and Certification,

Chernihiv, Ukraine

https://orcid.org/0000-0001-6341-8381

Dmytro Kamak

Chief of the Scientific-Research Department of State Scientific Research Institute of Armament and Military Equipment Testing and Certification, Chernihiv, Ukraine

https://orcid.org/0000-0003-0348-5456

\title{
АЛГОРИТМ СОКРАЩЕНИЯ КОЛИЧЕСТВА ОПЫТОВ ПРИ ИСПОЛЬЗОВАНИИ ИНТЕРВАЛЬНЫХ ОЦЕНОК КАЧЕСТВА ИСПЫТЫВАЕМОГО ОБРАЗЦА ВООРУЖЕНИЯ И ВОЕННОЙ ТЕХНИКИ
}

\author{
И.В. Корниенко, С.П. Корниенко, В.А. Дмитриев, А.Г. Павленко, Д.А. Камак
}

Сокращение расходов материальных и временных ресурсов, которые необходимы для планирования, проведения и обработки результатов испытаний вооружения и военной техники является одним из важных факторов, который влияет на общую эффективность функиионирования испытательного института. В статье рассмотрены теоретические вопросы формирования необходимых и достаточных условий для обеспечения качества интервальных оценок исследуемых стохастических параметров и характеристик испытуемых образиов вооружения и военной техники. Особенностью использования интервальной оценки результатов испытания образиов, является подтверждение надлежамего качества их стохастических параметров и характеристик в интервале от гарантированной разработчиком вероятности реализации параметра или характеристики до максимальной (минимальной) возможной. 3 а счет использования интервальных оценок возможно применение гибких планов испытания образиов вооружения и военной техники, которые позволяют определенным образом сокрамать объем серий натурных опытов, и которые обеспечивают надлежащее качество получаемой оценки. Для реализации гибкого плана разработан несложный итерачионный механизм, которой позволяет прекратить серию испьтаний, если на определенном этапе повторений оценка исследуемого параметра (характеристики) достигла заданной надежности и точности, при этом вероятность реализачии по количеству проведенных опытов, представляется не хуже заданной разработчиком величины. Для практической реализачии гибкого плана к задаче массовых испытаний образиов вооружения и военной техники разработан алгоритм, который подлежит программной реализаџии на мобильном устройстве. Предполагается, что использование мобильного устройства при проведении испытаний позволит в полевых условиях, при условии получения положительных результатов испытаний, досрочно прекратить серию опытов испытания образца вооружения и военной техники.

Ключевые слова: автоматизачия, испытания, оценка, точность, надежность, вооружение и военная техника.

\section{ALGORITHM FOR REDUCING THE NUMBER OF EXPERIMENTS USING INTERVAL QUALITY ASSESSMENTS OF TEST SAMPLE OF WEAPONS AND MILITARY EQUIPMENT}

\author{
I. Korniienko, S. Korniienko, V. Dmytriiev, A. Pavlenko, D. Kamak
}

Reducing the cost of material and time resources required for planning, conducting and processing the results of tests of armaments and military equipment is one of the important factors that affect the overall efficiency of the test institute. Costs, especially of time, have a significant impact on the total number of tests that a testing institute can perform. Therefore, the issue of cost reduction in testing does not lose its relevance. The article considers the theoretical issues of forming the necessary and sufficient conditions to ensure the quality of interval estimates of the studied stochastic parameters and characteristics of the tested samples of weapons and military equipment. The peculiarity of using interval evaluation of test results is the confirmation of the proper quality of their stochastic parameters and characteristics in the range from the probability of realization of the parameter or characteristic guaranteed by the developer to the maximum (minimum) possible. Due to the use of interval estimates, it is possible to use flexible plans for testing samples of weapons and military equipment, which allow reducing in some way the volume of a series of field experiments that ensure the proper quality of the obtained estimate. To implement a flexible plan, a simple iterative mechanism has been developed, which allows to stop a series of tests if at a certain step of repetition the estimation of the studied parameter (characteristic) has reached the set reliability and accuracy. In this case, the probability of implementation, according to the number of experiments, is not worse than the value specified by the developer. For the practical implementation of a flexible plan for the task of mass testing of samples of weapons and military equipment, an algorithm has been developed, which is subject to software implementation on a mobile device. It is assumed that the use of a mobile device during the tests will allow in the field, provided positive test results, to terminate a series of tests of a sample of weapons and military equipment.

Keywords: automation, testing, estimation, accuracy, reliability, armament and military equipment. 